\title{
Fruit quality characteristics of the Bulgarian sweet cherry cultivar 'Rozalina'
}

\author{
S. Savchovska ${ }^{1 *}$ and M. Nesheva ${ }^{1}$ \\ 1Fruit Growing Institute-Plovdiv, Bulgaria \\ *Corresponding author email: kirilova.savchovska93@abv.bg
}

\begin{abstract}
Sweet cherry (Prunus avium L.) is one of the most commercially important Prunus fruit tree species grown in Bulgaria. The current study aimed to describe the fruit quality of the Bulgarian bicolor sweet cherry cultivar 'Rozalina'. The study was conducted in 2021 and 'Van' and 'Pobeda Krimska' were used for comparison. The phenological stages flow, fruit biometric data, colorimetric analyses, fruit flesh firmness, and sensory evaluation of the studied cultivars are presented. Phenological observations show that the development of all three cultivars begins in early March. The 'Rozalina' cv. was the first to reach full maturity/04.06/, followed by 'Pobeda Krimska' /10.06/ and 'Van' /14.06/. Under the influence of late spring frost 'Rozalina' showed the lowest percentage of injured flowers. From the performed biometric measurements, it was established that the standard cultivar 'Van' surpasses the other two cultivars in fruit height, width, thickness, and fruit weight but 'Rozalina' had a better stone relative share. The Bulgarian cultivar had the highest TSS $\left({ }^{\circ} \mathrm{Brix}\right)$ content and fruit flesh firmness and its fruits were highly evaluated after sensory analyses.
\end{abstract}

Keywords: bicolor sweet cherry, biometry, colorimetric analyses, fruit quality, phenology, sensory evaluation

\section{INTRODUCTION}

Sweet cherry is a fruit species that belongs to the genus Prunus, family Rossaceae. It is one of the main fruit crops in Bulgaria. The fruits ripen very early in May and are the first on the market (Zhivondov and Manolova. 2001). They have attractive appearance and taste. In addition, sweet cherries are also known for their rich nutritional value content and the wide range of bioactive compounds (Cao et al., 2015). Unfortunately, harvesting is in a very narrow range of about two months. The early- or late-ripening genotypes that would extend the relatively short season for fruit ripening are sought after in the sweet cherry breeding program of Fruit Growing Institute (Zhivondov et al., 2003). Sweet cherries are consumed mainly fresh and are also suitable for processing into jam, wine, juice, dried fruits, candies, and other products. The fresh fruits are very volatile, their shelf life is only a few days and then transported to the markets they lose many of their qualities. The Way to keep them present in our menu throughout the whole year is fruits processing and drying methods (Wani et al., 2014; Singh et al., 2018). Drying reduces the moisture content of the fruit, leading to a significant reduction in weight, volume, and reduced costs for packaging, storage, and transport (Hui et al., 2005).

The program for breeding of new cherry cultivars in Fruit Growing Institute (FGI) - Plovdiv, Bulgaria includes objectives in line with the market trends and the constantly changing preferences of consumers. The specific goal of the selection program of the Fruit Growing 
Institute in Bulgaria is the creation of bicolor cherry cultivars. The first successful results in that direction are 'Rosita' and 'Rosalina' cultivars, officially recognized in 2009. 'Rosalina' cultivar, was obtained as a result of open pollination of 'Van' cultivar and selection of hybrids (Zhivondov, 2011)

\section{MATERIALS AND METHODS}

The study was conducted in 2021 in a collection of a sweet cherry orchard at the Fruit Growing Institute - Plovdiv. The trees were planted in 2011 at a 6x4 distance and grown under the black fallow system, with conventional plant protection. All cultivars are grafted on Prunus mahaleb and are formed a free-growing crown.

An object of the study was the Bulgarian bicolor cultivar 'Rozalina'. The standard cultivar with red fruits 'Van' and a cultivar with yellow fruits 'Pobeda krimska' were used for comparison. Phenological data was traced according to the stone fruits BBCH scale (Meier, 2018). In the spring of 2021 freezing temperatures occurred. The percentage of damaged flowers was calculated on 300 flowers taken into all parts of the crown, divided into three repetitions of 100 pcs.

The fresh fruit quality evaluation included biometrical, colorimetric, and sensory analyses. An average sample of 25 fruits was taken and biometric data was measured with Mitutoyo 500-196-30 Digimatic Absolute Caliper $150 \mathrm{~mm}$. Sweet cherry fruits were subject to color evaluation in the CIE L*a*b* system including hue angle (h) and chroma (c), using handheld colorimeter PCE-CSM 2. Measurements were made at the equatorial part on both sides of 10 fruits. The $0 \mathrm{~L}^{*}$ values represent the black color, 100-represents a perfect reflecting diffuser (bright). A positive $a^{*}$ value indicates red and a negative $a^{*}$ value green color, a positive $b^{*}$ value indicates yellow, and a negative $b^{*}$ value blue color. Fruit firmness was measured using PCE-PTR-200N digital penetrometer. The total soluble solids content was measured using digital refractometer Kern ORF 85BM.

For sensory evaluation of the fresh fruits, a total number of 8 characteristics were scored by a group of trained consumers using the following scale: $1-3(\mathrm{~min})$ very bad to bad; 3-4satisfactory; 5-6 better, and 7-9 (max)- excellent. Each characteristic was multiplied by a coefficient depending on its importance: 0.175 for appearance, 0.050 for flavor attractiveness and 0.225 for flavor intensity, 0.200 for sweetness, 0.125 for sour taste, 0.125 for bitterness, 0.200 for flavor balance, and 0.150 for fruit flesh texture and juiciness.

The fresh fruits were used for preparing homemade dry fruits by a dehydrator. Their taste quality was evaluated by a group of trained consumers using the following scale: $1-3(\mathrm{~min})$ very bad to bad; 3-4-satisfactory; 5-6 better and 7-9 (max)- excellent. The final grade was calculated using the following characteristics and coefficients: 0.200 for appearance, 0.125 for color, -0.025 for peel thickness, 0.200 for sweet taste, 0.125 for sour taste, -0.025 for bitterness, 0.200 for flavor balance, and 0.200 for texture.

Data were statistically processed by Duncan's multiple range test of the IBM SPSS statistics 26 software.

\section{RESULTS AND DISCUSSIONS}

The phenological stages of the cultivars depend on a combination of genetic settings and environmental influences. The development of flower buds in the studied three sweet cherry cultivars begins in early March with two to three days difference (Table 1). The phenophase 'beginning of flowering' (BBCH 61) first occurred for 'Pobeda Krimka' on 11.04, followed by 'Rosalina' on 12.04. and the standard Van - 13.04. The duration of flowering for all three cultivars was four days. The longer flowering period allows better pollination. End of 
flowering, 'falling of the petals' was observed with the minimum difference between all three cultivars - 'Pobeda Krimska' (April 17, 2021), 'Rosalina' (April 18, 2021) and 'Van' (April 20, 2021). In the past years in the Plovdiv region, critically low spring temperatures overlap with the early flowering of the cherry. Different cultivars that fall under the influence of late spring frosts in the same phenophase show different sensitivity of the flower organs (Popov, 2014). In 2021 also, during the development of the flower organs, spring frosts were observed, which harmed the flowering. Of these three sweet cherry cultivars subject to the present study, the lowest percentage of frost injured flowers was reported for 'Rosalina' - 43\%. The highest percentage of damaged flowers was reported for the standard 'Van' - 57\%.

Table 1. Phenological stages flow and frost damages

\begin{tabular}{|c|c|c|c|c|c|c|}
\hline Cultivar & $\begin{array}{c}\text { Buds } \\
\text { swelling } \\
\text { (BBCH51) } \\
\text { Date }\end{array}$ & $\begin{array}{c}\text { Beginning of } \\
\text { flowering } \\
\text { (BBCH 61) } \\
\text { Date }\end{array}$ & $\begin{array}{c}\text { Full } \\
\text { Flowering } \\
\text { (BBCH 65) } \\
\text { Date }\end{array}$ & $\begin{array}{c}\text { Flowers } \\
\text { fading } \\
\text { (BBCH 67) } \\
\text { Date }\end{array}$ & $\begin{array}{c}\text { Harvest date } \\
\text { (BBCH 89) } \\
\text { Date }\end{array}$ & $\begin{array}{c}\text { Frost } \\
\text { damaged } \\
\text { flowers } \\
(\%)\end{array}$ \\
\hline 'Rozalina' & 1.03 & 12.04 & 15.04 & 18.04 & 4.06 & $43 \%$ \\
\hline 'Van' & 2.03 & 13.04 & 16.04 & 20.04 & 14.06 & $57 \%$ \\
\hline $\begin{array}{c}\text { 'Pobeda } \\
\text { Krimska' }\end{array}$ & 1.03 & 11.04 & 14.04 & 17.04 & 10.06 & $52,3 \%$ \\
\hline
\end{tabular}

The fruit biometrical data is presented in Table 2. The standard cultivar 'Van' had the largest fruits with statistically the highest measured sizes and fruit weight. The Bulgarian cultivar 'Rozalina' had the smallest stone weight and the best stone relative share $-2.89 \%$ of the fruit weight. Total soluble solids are one of the best indicators of fruit quality (Kappel et al., 1996). The rate of accumulation of sugars, which constitute the largest part of TSS, depends on the cultivar and the ecological conditions in which the trees are grown (Kappel et. al., 1996). Fruit firmness is also highly appreciated by consumers. According to these characteristics, 'Rozalina' outperforms the other cultivars with statistically significant differences (Figure 1 and Figure 2). The Bulgarian cultivar had the highest TSS content and the hardest fruits.

Table 2. Fruit biometrical analyses

\begin{tabular}{|c|c|c|c|c|c|c|}
\hline Cultivar & $\begin{array}{c}\text { Fruit } \\
\text { height } \\
(\mathrm{mm})\end{array}$ & $\begin{array}{c}\text { Fruit } \\
\text { width } \\
(\mathrm{mm})\end{array}$ & $\begin{array}{c}\text { Fruit } \\
\text { thickness } \\
(\mathrm{mm})\end{array}$ & $\begin{array}{c}\text { Fruit } \\
\text { weight } \\
(\mathrm{g})\end{array}$ & $\begin{array}{c}\text { Stone } \\
\text { weight } \\
(\mathrm{g})\end{array}$ & $\begin{array}{c}\text { Stone } \\
\text { relative } \\
\text { share (\%) }\end{array}$ \\
\hline 'Rozalina' & $23.75 \mathrm{~b}$ & $26.20 \mathrm{~b}$ & $21.51 \mathrm{~b}$ & $9.04 \mathrm{~b}$ & $0.26 \mathrm{~b}$ & $2.89 \mathrm{c}$ \\
\hline $\begin{array}{c}\text { 'Pobeda } \\
\text { Krimska' }\end{array}$ & $21.41 \mathrm{c}$ & $22.51 \mathrm{c}$ & $19.57 \mathrm{c}$ & $5.94 \mathrm{c}$ & $0.35 \mathrm{a}$ & $5.86 \mathrm{a}$ \\
\hline 'Van' & $24.24 \mathrm{a}$ & $26.91 \mathrm{a}$ & $22.04 \mathrm{a}$ & $9.59 \mathrm{a}$ & $0.34 \mathrm{a}$ & $3.56 \mathrm{~b}$ \\
\hline
\end{tabular}

*Mean values followed by a different letter show a statistically significant difference by Duncan's multiple range test $(p<0.05)$ 


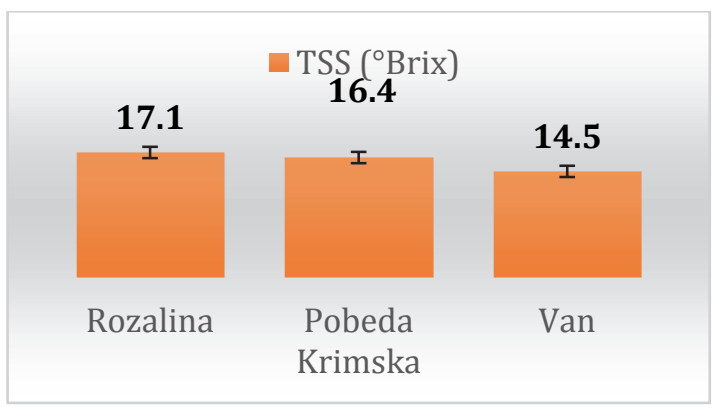

Figure 1. Fruit total soluble solids content

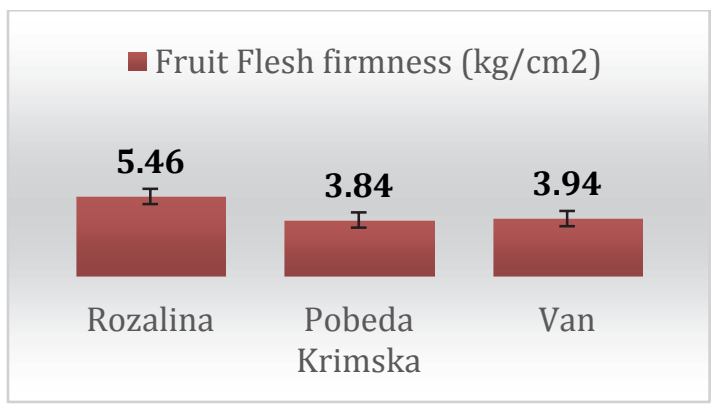

Figure 2. Fruit flesh firmness

Concerning the skin color parameters, significant differences were observed between the cultivars. The measured $\mathrm{H}$ value for both sides of the fruits of 'Rozalina' represents its bicolor fruit skin (Table 3). The minimum difference in the color parameters measured on both sides of the fruits of 'Van' and 'Pobeda Krimska' shows us their uniform coloration. The hue angle values of 'Pobeda Krimska' corresponded to the yellow-green skin color, for 'Van', the hue values corresponded to the red coloration. 'Pobeda Krimska' and 'Rozalina' had brighter coloration and the highest $\mathrm{L}^{*}$ value. According to the $\mathrm{a}^{*}$ and $\mathrm{b}^{*}$ values of the skin color, 'Rozalina' had a higher proportion of red pigment than 'Pobeda Krimska' and lower than 'Van'. 'Rozalina's' fruits have yellow skin with attractive bright red blush on the sunny side (Figure 3), with the highest measured Chroma.

Table 3. Color of the fruits

\begin{tabular}{|c|c|c|c|c|c|}
\hline \multicolumn{7}{|c|}{ Skin color } \\
\hline Cultivar & $L$ & $a$ & $b$ & Chroma & Hue \\
\hline 'Rozalina' & $64.96 \mathrm{a}$ & $12.02 \mathrm{~b}$ & $23.20 \mathrm{a}$ & $26.95 \mathrm{a}$ & $63.10 \mathrm{~b}$ \\
\hline 'Pobeda Krimska' & $66.05 \mathrm{a}$ & $2.69 \mathrm{c}$ & $25.40 \mathrm{a}$ & $25.54 \mathrm{a}$ & $83.96 \mathrm{a}$ \\
\hline 'Van' & $32.40 \mathrm{~b}$ & $22.36 \mathrm{a}$ & $3.92 \mathrm{~b}$ & $22.72 \mathrm{a}$ & $11.49 \mathrm{c}$ \\
\hline \multicolumn{7}{|c|}{ Skin color on the sunny side } \\
\hline Cultivar & $L$ & $a$ & $b$ & Chroma & Hue \\
\hline 'Rozalina' & $50.54 \mathrm{~b}$ & $32.06 \mathrm{a}$ & $16.92 \mathrm{~b}$ & $36.30 \mathrm{a}$ & $28.00 \mathrm{~b}$ \\
\hline 'Pobeda Krimska' & $67.72 \mathrm{a}$ & $2.76 \mathrm{c}$ & $25.81 \mathrm{a}$ & $25.96 \mathrm{~b}$ & $83.92 \mathrm{a}$ \\
\hline 'Van' & $32.21 \mathrm{c}$ & $27.16 \mathrm{~b}$ & $8.06 \mathrm{c}$ & $28.43 \mathrm{~b}$ & $16.47 \mathrm{c}$ \\
\hline
\end{tabular}

*Mean values followed by a different letter show a statistically significant difference by Duncan's multiple range test $(p<0.05)$
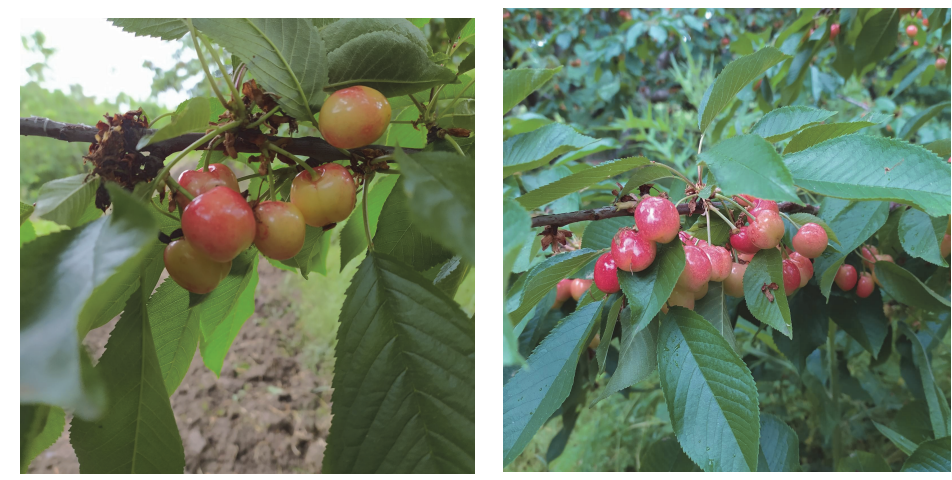

Figure 3. Fruits of 'Rozalina' $c v$. 
Fruit quality is a combination of physical and chemical characteristics appearance, consistency, taste, and aroma (Velisek and Cejpek, 2007). The customers prefer dark red sweet cherries, instead of other skin colors. Yellow, blush, and bicolor cultivars are preferred in Japan. The sweet taste and firm flesh are very important for the final consumers worldwide (Bujdoso et al., 2020). After the sensory evaluation of the three testes sweet cherry cultivars the most attractive were found to be the fruits of 'Van'. 'Rozalina' had the highest scores for its aroma and taste qualities and the fresh fruit's final grade was also the highest.

The fruits of the Bulgarian cultivar are suitable for drying. The testing panel of trained consumers evaluated very high the homemade dried product. 'Rozalina' had higher scores for its appearance, taste, and texture than both other cultivars.

Table 4. Sensory evaluation of fresh and dry fruits

\begin{tabular}{|c|c|c|c|c|c|c|c|c|c|}
\hline \multicolumn{10}{|c|}{ Fresh fruits } \\
\hline \multirow[b]{2}{*}{ Cultivar } & \multirow[b]{2}{*}{$\begin{array}{l}\text { Appearanc } \\
\text { e }\end{array}$} & \multicolumn{2}{|c|}{ Aroma } & \multicolumn{4}{|c|}{ Taste } & \multirow{2}{*}{$\begin{array}{c}\text { Fruit } \\
\text { flesh } \\
\text { texture } \\
\text { and } \\
\text { juiciness }\end{array}$} & \multirow[b]{2}{*}{$\begin{array}{c}\text { Final } \\
\text { evaluation }\end{array}$} \\
\hline & & Attractive & Intensity & Sweet & Sour & $\begin{array}{l}\text { Bitte } \\
r\end{array}$ & Balance & & \\
\hline 'Rozalina' & 8 & 7.2 & 7.2 & 7.2 & 5.4 & 1.8 & 7.6 & 8 & 7.82 \\
\hline $\begin{array}{l}\text { 'Pobeda } \\
\text { Krimska' }\end{array}$ & 6 & 4.8 & 5 & 6.6 & 4.4 & 2 & 5,4 & 5.2 & 5.69 \\
\hline 'Van' & 8.4 & 7.2 & 6.8 & 7 & 3.6 & 2.2 & 7.2 & 7.8 & 7.48 \\
\hline \multicolumn{10}{|c|}{ Dry fruits } \\
\hline Cultivar & $\begin{array}{l}\text { Appearanc } \\
\text { e }\end{array}$ & Color & $\begin{array}{c}\text { Skin } \\
\text { thickness }\end{array}$ & Sweet & Sour & $\begin{array}{l}\text { Bitte } \\
\mathrm{r}\end{array}$ & Balance & Texture & $\begin{array}{c}\text { Final } \\
\text { evaluation }\end{array}$ \\
\hline 'Rozalina' & 8.43 & 8.29 & 7.29 & 8 & 2.71 & 1.14 & 8 & 8.57 & 7.76 \\
\hline $\begin{array}{l}\text { 'Pobeda } \\
\text { Krimska' }\end{array}$ & 6.14 & 5.71 & 6.43 & 7.14 & 3.13 & 1.29 & 7.43 & 7.71 & 6.60 \\
\hline 'Van' & 7.57 & 8.43 & 7 & 6.57 & 3.86 & 1.14 & 6.57 & 7.29 & 6.93 \\
\hline
\end{tabular}

\section{CONCLUSIONS}

'Rozalina' is a Bulgarian sweet cherry cultivar with very good fruit quality. Its fruits are bicolor, a firm with high TSS content. The fruits have very good taste quality. They are suitable for fresh consumption and highly appreciated when dried. 'Rozalina' has better frost resistance than the standard cultivar 'Van' but in years with extreme late spring frosts the productivity of the cultivar may decrease.

\section{ACKNOWLEDGEMENTS}

The authors would like to express special gratitude to Prof. Argir Zhivondov, Ph.D., for providing the plant materials and Svetla Pandova and Leyda Todorova for the technical support.

\section{REFERENCES}

1. Bujdoso, G., Hrotko, K., Feldmane, D., Giovannini, D., Demirsoy, H., Tao, R., Ercisli S., Ertek N. and Malchev, S. (2020). What Kind of sweet cherries do the Final consumers prefer? South-west J Hortic Biol Environ, 11(1): 37-48.

2. Cao, J., Jiang, Q., Lin, J., Li, X., Sun, C., and Chen, K. (2015). Physicochemical characterization of four cherry species (Prunus spp.) grown in China. Food Chemistry, 173: 855-863.

3. Duncan, D. B. (1955). Multiple ranges and multiple F tests. Biometrics, 11(1): 1-42.

4. Hui, Y.H., Sherkat, F. (2005). Handbook of food science, technology, and engineering. 
5. Jemric, T. (2000). Sweet cherry fruit growth and carbohydrate accumulation. MSc Thesis. The University of Zagreb, Faculty of Agriculture p.78.

6. Kappel, F., Fisher-Fleming, B. and Hogue, E. (1996). Fruit characteristics and sensory attributes of an ideal sweet cherry. HortScience 31(3):443-446.

7. Meier, U. (2018). Growth stages of mono-and dicotyledonous plants: BBCH Monograph. Open Agrar Repositorium, Quedlinburg.

8. Popov, S. (2014). The effect of low temperatures on the reproductive organs of Bigarreau Burlat and Summit cultivars grafted on different rootstocks. Plant Science (Bulgaria).

9. Singh, P., Shrivastava, V., \& Kumar, A. (2018). Recent developments in greenhouse solar drying: A review. Renewable and sustainable energy reviews, 82, 3250-3262.

10. Velisek, J., and Cejpek, K. (2007). Biosynthesis of food constituents: vitamins. 1. Fat-soluble vitamins - a review. Czech J. Food Sci. 25 (1): 1-16

11. Wani, A. A., Singh, P., Gul, K., Wani, M. H., and Langowski, H. C. (2014). Sweet cherry (Prunus avium): Critical factors affecting the composition and shelf life. Food packaging and Shelf life, 1(1): 86-99.

12. Zhivondov A., Manolova V. (2001). Economical evaluation of early and medium early cherry cultivars. Rastenievadni Nauki (Plant Science, Sofia), 38 (1): 34-39.

13. Zhivondov, A. (2011). 'Rosalina'-a new bicolor cherry cultivar. In II Balkan Symposium on Fruit Growing 981: 201-203.

14. Zhivondov, A., Gercheva, P., and Djouvinov, V. (2003). Some results of a sweet cherry breeding program in Bulgaria. In XI Eucarpia Symposium on Fruit Breeding and Genetics 663: 739-742. 